\title{
Authigenic carbonates related to active seepage of methane-rich hot brines at the Cheops mud volcano, Menes caldera (Nile deep-sea fan, eastern Mediterranean Sea)
}

\author{
Catherine Pierre ${ }^{1,{ }^{*}}$, Germain Bayon ${ }^{2}$, Marie-Madeleine Blanc-Valleron $^{3}$, Jean Mascle ${ }^{4}$, \\ Stéphanie Duprée
}

\author{
1 Université Pierre et Marie Curie, LOCEAN (UMR 7159), 4 Place Jussieu, 75252, Paris Cedex 05, France \\ 2 IFREMER, Géosciences Marines, 29280, Plouzané Cedex, France \\ ${ }^{3}$ CR2P (UMR 7207), 57 rue Cuvier, CP 48, 75005, Paris, France \\ ${ }^{4}$ Observatoire Océanologique, BP 48, 06235, Villefranche-sur-mer, France
}

*: Corresponding author : Catherine Pierre, email address : catherine.pierre@locean-ipsl.upmc.fr

\begin{abstract}
:
On the passive margin of the Nile deep-sea fan, the active Cheops mud volcano (MV; ca. 1,500 m diameter, 20-30 m above seafloor, 3,010-3,020 m water depth) comprises a crater lake with hot (up to ca. $42{ }^{\circ} \mathrm{C}$ ) methane-rich muddy brines in places overflowing down the MV flanks. During the Medeco2 cruise in fall 2007, ROV dives enabled detailed sampling of the brine fluid, bottom lake sediments at ca. $450 \mathrm{~m}$ lake depth, sub-surface sediments from the MV flanks, and carbonate crusts at the MV foot. Based on mineralogical, elemental and stable isotope analyses, this study aims at exploring the origin of the brine fluid and the key biogeochemical processes controlling the formation of these deep-sea authigenic carbonates. In addition to their patchy occurrence in crusts outcropping at the seafloor, authigenic carbonates occur as small concretions disseminated within sub-seafloor sediments, as well as in the bottom sediments and muddy brine of the crater lake. Aragonite and Mgcalcite dominate in the carbonate crusts and in sub-seafloor concretions at the MV foot, whereas Mgcalcite, dolomite and ankerite dominate in the muddy brine lake and in sub-seafloor concretions near the crater rim. The carbonate crusts and sub-seafloor concretions at the MV foot precipitated in isotopic equilibrium with bottom seawater temperature; their low $\delta^{13} \mathrm{C}$ values $(-42.6$ to $-24.5 \%)$ indicate that anaerobic oxidation of methane was the main driver of carbonate precipitation. By contrast, carbonates from the muddy lake brine, bottom lake concretions and crater rim concretions display much higher $\delta^{13} \mathrm{C}$ (up to $-5.2 \%$ ) and low $\delta^{18} \mathrm{O}$ values (down to $-2.8 \%$ ); this is consistent with their formation in warm fluids of deep origin characterized by ${ }^{13} \mathrm{C}$-rich $\mathrm{CO}_{2}$ and, as confirmed by independent evidence, slightly higher heavy rare earth element signatures, the main driver of carbonate precipitation being methanogenesis. Moreover, the benthic activity within the seafloor sediment enhances aerobic oxidation of methane and of sulphide that promotes carbonate dissolution and gypsum precipitation. These findings imply that the coupling of carbon and sulphur microbial reactions represents the major link for the transfer of elements and for carbon isotope fractionation between fluids and authigenic minerals. A new challenge awaiting future studies in cold seep environments is to expand this work to oxidized and reduced sulphur authigenic minerals.
\end{abstract}


In the eastern Mediterranean Sea, active methane seeps associated with mud volcanoes and pockmarks are widely distributed both on the active margin of the Mediterranean Ridge and on the passive margin of the Nile deep-sea fan (Loncke et al. 2004; Huguen et al. 2005; Mascle and Mascle 2012; Mascle et al., this volume). Previous findings from the Medinaut, Nautinil and Bionil expeditions have shown that authigenic carbonate formations are closely associated with these seepage structures (Aloisi et al. 2000; Huguen et al. 2005, 2009; Gontharet et al. 2007; Bayon et al. 2009, 2013). Subsurface geophysical exploration has demonstrated that deep-seated fractures act as natural conduits for overpressured fluids expelled to the seafloor (Huguen et al. 2004, 2009; Dupré et al., this volume). Moreover, the presence of thick Messinian evaporites (1 to $2 \mathrm{~km}$ subbottom depth) in the deep parts of the Mediterranean basins impacts directly on fluid chemistry, generating warm hydrocarbon-rich (i.e. mostly $\mathrm{CH}_{4}$ associated to heavier hydrocarbon gases, Mastalerz et al. 2009) brines that migrate through the sediments and reach the seafloor where they accumulate in morphological depressions to form deep-sea "brine lakes" (Loncke and Mascle 2004; Huguen et al. 2009). Whereas methane seepage and associated seeprelated structures (e.g. pockmarks and mud volcanoes) have been the subject of numerous studies worldwide (see Judd and Hovland 2007), brine-related seepage has been poorly investigated on continental margins. Some well-known brine sites include those of the Gulf of Mexico (Joye et al. 2009) and the eastern Mediterranean Sea. The latter exhibits active brine mud volcanoes along the Mediterranean Ridge (Woodside and Volgin 1996; Huguen et al. 2005), and also in the western Nile province of the Nile deep-sea fan-the Menes mud volcano caldera complex (Foucher et al. 2009; Huguen et al. 2009).

The present study aims to characterize the geochemistry (mineralogy, major and trace elements, oxygen and carbon isotopes) of authigenic carbonates from the muddy brine, concretions and crusts of the Cheops mud volcano (MV) collected during the Medeco2 cruise of fall 2007. These new results complement previous data obtained on two carbonate crusts from this mud volcano (Gontharet et al. 2007) and provide more detailed information on fluid-mineral interactions controlled by key biogeochemical processes at the seafloor and within the brine lake. This specific case of active seepage of hot muddy methane-rich brine is then integrated within the general context of eastern Mediterranean Sea so-called cold seeps.

\section{Geological setting}

The Nile deep-sea fan (NDSF) represents a vast area $\left(\sim 100,000 \mathrm{~km}^{2}\right)$ on the Egyptian passive continental margin resulting from the accumulation of a pile 1-2 km thick of terrigenous sediments deposited by the river Nile during the Plio-Pleistocene (Loncke et al. 2006). Numerous seafloor structures (gas chimneys, mud volcanoes, mud pies, pockmarks) related to fluid venting have been identified on the upper slope down to the abyssal plain, based on swath bathymetry and other geophysical investigations (Loncke et al. 2004). The Menes caldera in the western province of the NDSF (Fig. 1a) is a circular depression up to $8 \mathrm{~km}$ in diameter and $100 \mathrm{~m}$ deep at $\sim 3,000 \mathrm{~m}$ water depth (Fig. $1 \mathrm{~b})$. It comprises several active and non-active mud volcanoes, as observed on backscatter imagery (Dupré et al. 2008; Huguen et al. 2009).

The Cheops MV has a diameter of about $1500 \mathrm{~m}$ and rises $\sim 20-30 \mathrm{~m}$ above the seafloor at about $3,010-3,020 \mathrm{~m}$ water depth. Its otherwise rather flat summit is characterized by a large muddy brine lake with an average diameter of $\sim 250 \mathrm{~m}$ (Figs. 2 and 3) and at least $449 \mathrm{~m}$ deep in places (Dupré et al., this volume), surrounded by a sub-circular depression filled with relatively clear brine. According to highresolution backscatter data, the muddy brines are today overflowing down the northern flank of the mud volcano; older brine flows have spilled down the north and east flanks (Fig. 2; Dupré et al. 2008). The surface of muddy brines in the lake is partly covered by whitish filaments (Fig. 3a) of sulphur-oxidizing bacteria identified as Candidatus Arcobacter sulfidicus (determination by L. Toffin in Pierre et al. 2008); these bacteria produce elemental $S$ filaments, and have also been observed in a white mat covering the brine lake of the neighbouring Chephren MV (Omoregie et al. 2008). The crater lake surface shows a 
patchwork of circular pools from a few decimetres up to a few meters in diameter (Fig. 3b and c). Spiral streamlines underlined by white microbial mats originate from the inner parts of the pools where the muddy brine is being expelled (Fig. 3c), attesting to ongoing seepage.

The rim of the Cheops MV is characterized by very fluid, gassy grey mud breccia populated by crabs. Fresh mudflows have a $\mathrm{cm}$-thick cover of black reduced sediment over light grey stiff hemipelagic sediment, colonized by small polychaetes (Fig. 3d). Authigenic carbonate crusts are abundant at the foot of the north-eastern and western flanks of the mud volcano, where they outcrop as a patchy pavement a few $\mathrm{cm}$ thick and interspersed with reduced black sediment commonly covered with white microbial mats (Fig. 4a, b). The carbonate crusts have a porous structure with mm-size sub-circular cavities (Fig. 4c, d).

\section{Materials and methods}

In the late fall (2-30 November) of 2007, the Medeco2 cruise onboard the R/V Pourquoi pas ? investigated various deep eastern Mediterranean cold seep ecosystems, including the Menes caldera. The active Cheops MV was explored during four dives of the Victor 6000 ROV (remotely operated vehicle), two (nos. 340 and 344) dedicated to high-resolution bathymetric, backscatter and photographic exploration of the seafloor, and two others (nos. 342 and 343) to in situ multidisciplinary sampling and measurements (for overview, see Pierre et al. 2008). Samples for mineralogical and geochemical analyses were collected from the muddy brine, from bottom sediments of the crater lake and subseafloor sediments of the NE and SE flanks of the mud volcano, and from carbonate crusts outcropping at the foot of the NE flank (for sample locations, water depths, etc., see Fig. 2 and Table 1).

In the crater lake, muddy brine was sampled using Niskin bottles deployed by the ROV arm. Measurements of salinity and methane concentration were conducted onboard immediately upon recovery of the bulk samples. Salinity varied in the range $210-244 \mathrm{~g} \mathrm{~L}^{-1}$ and methane concentrations were very high at 2.44-3.74 mmol L $^{-1}$ (data from V. Mastalerz in Pierre et al 2008). The temperature of the brine measured during sediment coring within the crater lake (also see below) displayed a marked increase from $14{ }^{\circ} \mathrm{C}$ at the lake surface (cf. local Mediterranean bottom water temperature) to about $42.1 \pm 1.1^{\circ} \mathrm{C}$ as of $18 \mathrm{~m}$ lake depth down to the deepest point of measurement at $449 \mathrm{~m}$ (cf. Dupré et al., this volume). The brine samples were stored in the ship's cool room (ca. $4^{\circ} \mathrm{C}$ ) until back ashore. In the laboratory, these were filtered through a nylon membrane filter $(0.8 \mu \mathrm{m})$, and the filtered material then rinsed with distilled water and oven dried at $60^{\circ} \mathrm{C}$.

A gravity corer equipped with thermal probes was deployed in the south-western sector of the brine lake (MD2-GCT6, Fig. 2). Only the core catcher recovered sediments. At this site, the brine-bottom sediment interface was reached at $449 \mathrm{~m}$ below the surface of the lake, when it was decided to stop the corer for safety reasons (see Dupré et al., this volume).

Moreover, one push-core (MD2-343-PC9) and one blade-core (MD2-342-BC5) were collected by the Victor ROV, the former in a patch of reduced sediment with polychaetes at the foot of the northeast flank of the mud volcano. The latter was taken in mud breccia at the top of the southeast flank near the crater rim. Core sections were cut onboard ship and stored at $4{ }^{\circ} \mathrm{C}$ until processed in the laboratory when back ashore.

Sediment core subsamples were washed with distilled water, sieved at $150 \mu \mathrm{m}$, and the coarse (>150 $\mu \mathrm{m})$ and fine fractions $(<150 \mu \mathrm{m})$ oven dried at $60{ }^{\circ} \mathrm{C}$. The coarse fractions were then examined under the binocular microscope, revealing evidence of, amongst others, authigenic carbonate concretions. These were selectively handpicked and processed further for mineralogical and stable isotope analyses.

Carbonate crusts were sampled using the ROV at four locations near a smaller MV at the foot of the northeast flank of the Cheops MV (Fig. 2, Table 1). The samples were washed with distilled water and oven dried at $60{ }^{\circ} \mathrm{C}$ prior to further analyses (cf. below). 


\subsection{Mineralogy}

X-ray diffraction (XRD) analyses of carbonate crusts served to identify carbonate mineral composition (for raw data, see ESM Table 1 in the electronic supplementary material available online for this article). XRD analyses were made on randomly oriented powders using a Siemens D500 instrument (Cu Ka Ni filtered radiation, $40 \mathrm{kV}$ accelerating voltage, $30 \mathrm{~mA}$ current). The d104 values of calcite were used to estimate the relative mole $\% \mathrm{MgCO}_{3}$ in the crystal lattice (Goldsmith et al. 1961).

Scanning electron microscope (SEM) observations and elemental analyses of selected minerals with an energy dispersive X-ray spectrometer were performed on small fragments of carbonate crusts, various $\mathrm{mm}$-size concretions handpicked from sediments, and material filtered from the muddy brine.

\subsection{Major and trace elements}

The bulk major element compositions of carbonate crusts (MD2-342-CC1, MD2-343-CC1 and MD2-343CC2) were determined by wavelength-dispersive X-ray fluorescence (WDXRF, Brüker S8 Tiger). Trace element abundances in these samples and in two additional $\mathrm{mm}$-size whitish concretions from core MD2-GCT6 sediment were determined by ICP-SFMS at the Pôle Spectrométrie Océan (Brest). Prior to ICP-MS measurements, about $5 \mathrm{mg}$ of bulk carbonate powder were digested in $5 \%(\mathrm{v} / \mathrm{v}$ ) acetic acid (cf. Rongemaille et al. 2011). Rare earth elements were corrected for interferences, and concentrations of all trace elements were calculated using the Tm addition method (Barrat et al. 1996). These results are presented in Table 2.

\subsection{Stable isotopes}

Stable oxygen and carbon isotopic compositions are expressed in the conventional $\delta$ notation defined as $\delta=[(\operatorname{Rs} / \operatorname{Rr})-1] \times 1,000$, where $\mathrm{R}={ }^{18} \mathrm{O} / /^{16} \mathrm{O}$ or ${ }^{13} \mathrm{C} /{ }^{12} \mathrm{C}$ in the sample $\mathrm{s}$ and in the reference $\mathrm{r}$. The reference for $\delta^{18} \mathrm{O}$ and $\delta^{13} \mathrm{C}$ is the V-PDB (Craig 1957).

The oxygen and carbon isotopic compositions of carbonate were measured in the bulk carbonate fractions of carbonate crusts, bulk sediments filtered from the muddy brine, and individual concretions isolated from sediments (ESM Table 1 in the electronic supplementary material). The $\mathrm{CO}_{2}$ gas was extracted online from $\sim 100$ to $200 \mu \mathrm{g}$ of powdered sample treated with $100 \%$ phosphoric acid at $90{ }^{\circ} \mathrm{C}$, and analyzed with a dual-inlet isotopic ratio mass spectrometer (VG-Isoprime, Isoprime, Cheadle, UK) at LOCEAN, Paris. The analytical precision $2 \zeta$ is $0.01 \%$, and the reproducibility $\pm 0.05 \%$ for both $\delta^{18} \mathrm{O}$ and $\delta^{13} \mathrm{C}$.

\section{Results}

\subsection{Sediments and mineralogy}

The muddy brine from the Cheops crater lake is characterized by clay-size particles and detrital silicates associated with well-preserved coccoliths; authigenic minerals are represented by euhedral crystals of dolomite, ankerite, pyrite and barite (Fig. 5a-d).

Sediments recovered at the bottom of the crater lake (MD2-GCT6) consist of dark grey silty clay strongly impregnated with oily hydrocarbons. The coarse fraction includes well-preserved foraminifer tests, transparent and polished quartz grains, and mm-size rounded clasts of rock fragments. Authigenic minerals are present as aggregates of pyrite crystals, either isolated or included within carbonate concretions (Fig. 6a). In the carbonate concretions (Fig. 6b), Mg-calcite appears as oblong crystals with abundant dissolution cavities (Fig. 6c), associated with isolated or clustered $\mu \mathrm{m}$-size rhombs of ankerite (Fig. 6d). Sediments from the push core (MD2-343-PC9) and the blade core (MD2-342-BC5) were gas saturated with a strong hydrogen sulphide smell upon opening; they comprised homogenous finegrained mud breccia that were dark grey in the upper $5 \mathrm{~cm}$, corresponding to recent mudflows, grading to medium grey downwards in older mudflow deposits. The coarse fractions of all sediment samples are characterized by quartz grains, foraminifer tests, small (mm-size) clasts of rock fragments, and 
carbonate and pyrite concretions representing the authigenic components. The push core sediments also contained numerous transparent prismatic crystals of gypsum in the upper $4 \mathrm{~cm}$, and abundant carbonate-cemented mm-size tubeworms from 4 to $16 \mathrm{~cm}$ core depth. The carbonate concretions comprised Mg-calcite represented by $\mu \mathrm{m}$-size rounded rhombs (Fig. 7a) and larger ( $\sim 5 \mathrm{~m})$ platy lensoid crystals (Fig. 7b); euhedral rhombs $(\sim 5 \mu \mathrm{m})$ of ankerite are generally concentrated in veins between detrital grains (Fig. 7c); a few ankerite rhombs have a porous core made up of small Mg-calcite aggregates (Fig. $7 d$ ).

Authigenic carbonate crusts occur as light grey, thin and highly porous laminated deposits (Fig. 4a-c) that may form undulations and small mounds emerging from the seafloor. The crusts are made of mixtures of aragonite and $\mathrm{Mg}$-calcite $(16-20 \% \mathrm{MgCO} 3)$, aragonite being dominant $(71-89 \%$ of carbonate mixture); these cement the mud breccia and pelagic sediment components (Fig. $7 \mathrm{~d}$ ). Coccoliths are often recrystallized but nevertheless recognizable. Aragonite acicular crystals (Fig. 8a) may include particles from the sedimentary matrix (such as coccoliths); they commonly display numerous dissolution cavities (Fig. 8b) and are cemented or replaced by Mg-calcite (Fig. 8c). Pyrite is always present as framboids grouped within cavities (foraminifer chambers), isolated octahedrons or cubic crystals (Fig. $8 a)$. Locally, colonies of bacterial cells and aggregates of small $(<1 \mu \mathrm{m})$ rounded rhombs of ankerite may coat the aragonite needles (Fig. 8d).

\subsection{Major and trace elements}

The carbonate crusts are characterized by high amounts of detrital elements with, for example, $\mathrm{SiO}_{2}$ contents varying from $\sim 18$ to 28 wt\% (Fig. 9, Table 2). The crusts have high $\mathrm{Sr}(>6,500 \mathrm{ppm}$ ) and low Mg contents ( $\mathrm{MgO} \sim 1.10 \mathrm{wt} \%$ ); by comparison, the $5 \%$ acetic acid leachates of $\mathrm{mm}$-size carbonate concretions from core MD2-GCT6 exhibit similarly high Mg contents $(\sim 7,000 \mathrm{ppm})$ but much lower $\mathrm{Sr}$ contents $(<750 \mathrm{ppm})$. Interestingly, the trace element composition of the carbonate crusts differs strongly from that of these small concretions: several trace elements (e.g. Ba, Mo, $U$ ) display concentrations about one order of magnitude higher in authigenic crusts than in the MD2-GCT6 concretions (Table 2). By contrast, Mn contents in the crusts ( $<200 \mathrm{ppm}$ ) are much lower than in the $5 \%$ acetic acid leachates $(>3,000 \mathrm{ppm})$ of the concretions. Both the carbonate crusts and concretions display pronounced midREE enrichments; compared to the crusts, the concretions are slightly more enriched in heavy REEs.

\subsection{Oxygen and carbon isotopes}

Three groups of diagenetic carbonates (including data from Gontharet et al. 2007 on two carbonate crusts sampled during the Nautinil cruise along the western edge of the Cheops MV) can be differentiated by their oxygen and carbon isotopic compositions (Fig. 10, ESM Table 1 in the electronic supplementary material). One group corresponds to carbonate crusts from the foot of the mud volcano, which show consistently high $\delta^{18} \mathrm{O}$ values $\left(+2.9\right.$ to $+3.2 \%$ ) and very low (albeit more variable) $\delta^{13} \mathrm{C}$ values $(-42.6$ to $-29.8 \%$ ). The second group corresponds to carbonate concretions from sub-seafloor sediments at the foot of the northeast flank of the mud volcano, which display somewhat lower $\delta{ }^{18} \mathrm{O}(+1.5$ to $+2.8 \%$ ) and overall higher $\delta^{13} \mathrm{C}$ values $(-36.4$ to $-24.5 \%$ ).

The third group corresponds to carbonates from the crater lake and from near the crater rim, which have much lower $\delta^{18} \mathrm{O}$ and (except for one outlier for the bottom lake sediments) much higher $\delta^{13} \mathrm{C}$ signatures. This group comprises the muddy brine of the crater lake $\left(\delta^{18} \mathrm{O}\right.$ of -1.3 to $-0.7, \delta^{13} \mathrm{C}$ of -8.9 to -8.3 ), carbonate concretions from bottom lake sediments $\left(\delta^{18} \mathrm{O}\right.$ of -2.1 to $+1.7, \delta^{13} \mathrm{C}$ of -28.7 to -5.6$)$, and carbonate concretions from sub-seafloor sediments near the crater rim at the top of the southeast flank $\left(\delta^{18} \mathrm{O}\right.$ of -2.8 to $+1.3, \delta^{13} \mathrm{C}$ of -16.0 to -5.2$)$.

\section{Discussion}

Carbonate diagenesis in methane seep environments on active and passive continental margins is driven by microbial coupling of carbon and sulphur cycles. The main process usually is the anaerobic oxidation of methane (AOM), during which a consortium of anaerobic methanotrophic (ANME) archaea 
and sulphate-reducing bacteria (SRB) oxidizes methane to produce bicarbonate, and reduces sulphate to hydrogen sulphide (Boetius et al. 2000; Hinrichs et al. 2000; Orphan et al. 2001). Due to the high levels of alkalinity produced during $\mathrm{AOM}$ and released into solution, methane-derived authigenic carbonate (MDAC) precipitates in anoxic sediments (e.g. Claypool and Threlkeld 1983; Aloisi et al. 2000; Stadnitskaia et al. 2008; Gontharet et al. 2009; Pierre et al. 2012) and in anoxic bottom waters (e.g. Peckmann et al. 2001; Bayon et al. 2013). Because these authigenic carbonates register the geochemical and isotopic compositions and temperature of ambient pore waters during their precipitation, they can be used as tracers of abiotic and biotic (e.g. microbial) diagenetic processes.

\subsection{Biogeochemical processes}

Aragonite and Mg-calcite coexist in the carbonate crusts of the Cheops MV, with a dominance of aragonite over calcite. Various physicochemical factors controlling carbonate mineralogy, such as low sulphate and $\mathrm{Mg}$ concentrations in solution, would favour precipitation of calcite over aragonite (Burton and Walter 1987). Since seawater and brines originating from seawater commonly have high $\mathrm{Mg}$ concentrations, the microbial anaerobic processes of organoclastic sulphate reduction and AOM that consume the dissolved sulphate are thought to exert the main control on the aragonite-to-calcite mineralogy of authigenic carbonates (Aloisi et al. 2000; Gontharet et al. 2007). SEM observations of the Cheops MV authigenic carbonates revealed that aragonite represents the early carbonate phase to precipitate; Mg-calcite as well as ankerite precipitated during later stages probably when AOM had consumed all the sulphate available in pore solutions. This also explains why, in the muddy brine and in the carbonate concretions from reduced sediments at the lake bottom, aragonite is absent whereas Mgcalcite is associated with dolomite and iron-rich carbonates (mostly ankerite).

In iron-rich carbonates, the source of iron incorporated into the crystal lattice of minerals cannot be seawater, which contains only trace amounts of dissolved Fe; rather, the source is the in situ weathering of silicate minerals within anoxic sediments (Wallmann et al. 2008). The most common process of silicate weathering is hydrolysis, which produces clay minerals and releases cations and alkalinity; in turn, these can be combined to precipitate authigenic carbonates:

silicates $+\mathrm{CO}_{2}+\mathrm{H}_{2} \mathrm{O} \rightarrow$ clay minerals + cations + dissolved silica $+\mathrm{HCO}_{3}$

The $\mathrm{CO}_{2}$ may originate from aerobic oxidation of methane (AeOM) at the seafloor where oxygenated bottom water diffuses downwards or is channelled into sub-seafloor sediments by bioturbation. In that case, it is important to note that the release of $\mathrm{CO}_{2}$ in pore solutions would quickly dissolve solid carbonate; the porous texture and the dissolution cavities in aragonite crystals of carbonate crusts from the Cheops MV are probably related to such dissolution during AeOM. A similar explanation has been proposed for other cold seep authigenic carbonates of the eastern Mediterranean Sea (Himmler et al. 2011) and southwest Africa margin (Pierre et al. 2012). The importance of AeOM at the Cheops MV is confirmed by the very high total oxygen uptake $\left(111-130 \mathrm{mmol} \mathrm{O}_{2} \mathrm{~m}^{-2}\right.$ day $\left.^{-1}\right)$ in reduced sediments colonized by polychaetes, due to microbial consumption of oxygen mostly by methane oxidation (Boetius and Wenzhofer 2013). However, methane concentrations of 3.6-9.34 $\mu \mathrm{mol} \mathrm{L}^{-1}$ in bottom waters above these reduced sediments (Ritt et al. 2011) indicate that the efficiency of the microbial benthic filter is only $30 \%$ at this location (Boetius and Wenzhofer 2013).

Sulphide and sulphate authigenic minerals are also present in the Cheops MV sediments in association with carbonates, as classically described for cold seep environments. Pyrite may be considered as a byproduct of $\mathrm{AOM}$, taking into account the availability of $\mathrm{Fe}^{2+}$ in pore solutions (see below). By contrast, authigenic barite is considered to precipitate at the redox front corresponding to the sulphate-methane transition zone, where dissolved barium contained in methane-rich fluids combines with the dissolved sulphate of downward-diffusing seawater (Dickens 2001; Torres et al. 2003; Aloisi et al. 2004). In Fig. $5 \mathrm{~d}$, the barite crystal from the muddy brine of the Cheops MV was obviously precipitated in situ, including coccoliths and sediments during its growth probably at the interface between the brine surface and the overlying sulphate-rich seawater.

Another important diagenetic process that may arise in the suboxic zone, especially where benthic organisms are abundant, is sulphide $\left(\mathrm{H}_{2} \mathrm{~S}\right.$, pyrite) oxidation driven by microbial or inorganic reactions, 
which produces sulphate ions; these combine with calcium ions that have high concentrations in pore solutions due to previous calcium carbonate dissolution. This promotes the precipitation of authigenic gypsum crystals within sediment, as shown for the methane seeps of the Sea of Marmara and the southwest Africa margin (Crémière et al. 2012; Pierre et al. 2012). A similar interpretation is proposed to explain the occurrence of hyaline euhedral crystals of authigenic gypsum within sub-seafloor sediments at the foot of the Cheops MV; it can also be inferred that the benthic activity of abundant polychaetes observed at this site may have been responsible for the dynamic cycling of oxygen favouring AeOM at the sediment-bottom water interface.

A few $\mathrm{cm}$ deeper in the sediments, where full reducing conditions occur, Mg-calcite and ankerite are associated with pyrite in carbonate concretions; the overgrowth of ankerite on Mg-calcite crystals argue for the earlier precipitation of Mg-calcite that was probably partly dissolved prior to ankerite precipitation, as shown on Fig. 6d. In carbonate concretions from bottom lake sediments, there is also evidence of partial dissolution of $\mathrm{Mg}$-calcite crystals, whereas the associated ankerite is represented by perfect euhedral rhombs. These findings imply that venting fluids at the Cheops MV may contain both $\mathrm{CO}_{2}$, which would partly dissolve $\mathrm{Mg}$-calcite, and $\mathrm{CH}_{4}$ that was oxidized during $\mathrm{AOM}$ as bicarbonate further precipitated as ankerite. The biogeochemical process that may explain the co-occurrence of $\mathrm{CO}_{2}$ and $\mathrm{CH}_{4}$ in fluids is methanogenesis (the reaction below is presented with an acetate substrate):

$\mathrm{CH}_{3} \mathrm{COO}^{-}+\mathrm{H}^{+} \rightarrow \mathrm{CH}_{4}+\mathrm{CO}_{2}(2)$

Similar results have been obtained for an active mud volcano in the northern Gulf of Mexico (Joye et al. 2009), where microbial activity in muddy brine produces methane from acetate. The $\mathrm{CO}_{2}$ from the fluids thus appears as a very important component involved during diagenesis in anoxic sediments where two reactions are competing, i.e. carbonate dissolution and silicate weathering (reaction 1) leading to carbonate precipitation. Moreover, the combination of reactions 1 and 2 underlines that two types of authigenic carbonate phases may coexist in the same sediment, one carbonate phase originating from $\mathrm{CH}_{4}$ anaerobic oxidation and another from $\mathrm{CO}_{2}$ by silicate weathering.

\subsection{Sources of elements}

High contents of detrital elements within carbonate crusts of the Cheops MV indicate that these include various silicate minerals (quartz, feldspars, micas, clay minerals) from subsurface sediments, as confirmed by XRD analyses and SEM observations. The large differences between major and trace element concentrations are related to the mineralogy of authigenic carbonates, with high $\mathrm{Sr}$ and low $\mathrm{Mn}$ contents in the crusts dominated by aragonite, and low $\mathrm{Sr}$ and high $\mathrm{Mn}$ contents in the concretions dominated by dolomite and ankerite. To some extent, the higher $\mathrm{Ba}$ contents determined for the carbonate crusts relative to the small concretions could also reflect mineralogical differences, i.e. the presence of minor amounts of authigenic barite in the crusts. By contrast, the distribution of $U$ and Mo is most likely controlled by redox conditions during carbonate precipitation. While the relatively high Mo and $U$ contents in the authigenic crusts suggest that they formed under typical anoxic conditions, their lower abundance in the crater lake concretions could possibly point towards suboxic/oxic conditions. One interpretation would be that these concretions initially formed in the upper layers of the brine lake, at the interface between anoxic/suboxic lake waters and overlying oxic deep waters, before settling down onto the lake bottom. This hypothesis would also be supported by the corresponding REE distributions. The authigenic carbonate crusts had pronounced mid-REE enrichments, this being a typical feature of anoxic pore waters in cold seep settings (Bayon et al. 2011). By contrast, the small concretions are characterized by flatter mid- to heavy REE patterns and slightly negative $\mathrm{Ce}$ anomalies $\left(\mathrm{Ce} / \mathrm{Ce}^{*} \sim 0.91-\right.$ 0.96 , with $\mathrm{Ce} / \mathrm{Ce}^{*}=3^{*} \mathrm{CeN} /\left(2^{*} \mathrm{La}+\mathrm{Nd}\right) \mathrm{N}$ ), which could indicate a seawater origin (Bayon et al. 2013; Feng et al. 2013).

Alternatively, the slight enrichment of heavy REEs observed in the concretions recovered in bottom sediments of the brine lake could indicate that they precipitated from an alkaline-rich fluid source, possibly the $\mathrm{CO}_{2}$-rich fluid discussed above. Indeed, recent work has suggested that total alkalinity levels in pore waters could influence the distribution of REEs in cold seep carbonates (Rongemaille et al. 2011; Himmler et al. 2013), with highly alkaline fluids favouring precipitation of authigenic carbonates characterized by heavy REE enrichments. 


\subsection{Fluid-carbonate interactions}

The oxygen isotopic composition of a carbonate depends both on the temperature of precipitation and on the oxygen isotopic composition of the water; in addition, the fractionation of oxygen isotopes between water and carbonate differs for each carbonate mineral species. Based on this, an attempt is made below to reconstruct the diagenetic environmental conditions prevailing during carbonate precipitation. The following equations were used to calculate the isotopic equilibrium conditions for various carbonate minerals:

-calcite, Kim and O'Neil (1997); $\delta^{18} \mathrm{O}$ values for Mg-calcite were corrected by $+0.06 \%$ per mole $\% \mathrm{MgCO} 3$ (see Tarutani et al. 1969): $1,000 \mathrm{In} \alpha^{18} \mathrm{O}$ calcite-water $=18.03 * 10^{3} \mathrm{~T}^{-1}-32.42$

-aragonite, Grossman and Ku (1986); $\delta^{18} \mathrm{O}$ of aragonite and water in V-PDB and VSMOW respectively: T ${ }^{\circ} \mathrm{C}=21.8-4.69\left(\delta^{18} \mathrm{O}\right.$ aragonite $-\delta^{18} \mathrm{O}$ water $)$

-dolomite, Fritz and Smith (1970): 1,000 In $\alpha^{18} \mathrm{O}$ dolomite-water $=2.62 * 10^{6} \mathrm{~T}^{-2}+2.17$

-siderite, Carothers et al. (1988): $1,000 \ln \alpha^{18} \mathrm{O}$ siderite-water $=3.13^{*} 10^{6} \mathrm{~T}^{-2}-3.50$

-there is no experimental determination of the oxygen isotopic fractionation factor between ankerite and water, but the equilibrium $\delta^{18} \mathrm{O}$ value of ankerite can be roughly estimated to be intermediate between those of dolomite and siderite.

The $\delta^{18} \mathrm{O}$ values of carbonate (aragonite and $\mathrm{Mg}$-calcite) from the crusts and the small concretions from sub-seafloor sediments of the northeast flank of the Cheops MV (Fig. 10)

fall well within the range of equilibrium values calculated for aragonite $(+3.4 \%)$ and highMg-calcite $(+3.0$ to $+3.2 \%$ ) precipitated in present-day Mediterranean bottom waters ( $\mathrm{T}$ of $14{ }^{\circ} \mathrm{C}, \delta^{18} \mathrm{O}$ of $+1.6 \% \mathrm{~V}$ SMOW); this argues for recent (i.e. not older than the Holocene) precipitation of these authigenic carbonates. One concretion exhibits a slightly lower $\delta^{18} \mathrm{O}$ value $(+1.5 \% \mathrm{~V}-\mathrm{PDB})$, which could reflect precipitation in fluids about $5{ }^{\circ} \mathrm{C}$ warmer than present-day bottom waters.

Lower $\delta^{18} \mathrm{O}$ values recorded in the carbonate fraction of the muddy brine, the concretions from bottom brine lake sediments and the concretions from sub-seafloor sediments near the rim of the brine lake, characterized by variable proportions of the three major mineral components, i.e. high Mg-calcite, dolomite and ankerite, are obviously related to precipitation of these carbonates in hot brines. The equilibrium $\delta^{18} \mathrm{O}$ values calculated for high Mg-calcite, dolomite and ankerite precipitated within brine at $42{ }^{\circ} \mathrm{C}$ with a $\delta{ }^{18} \mathrm{O}$ value of $+1.6 \%$ would be $-2.5 \%,-0.3 \%$ and $-0.5 \%$ respectively. These values fit very well with the minimum value $(-2.8 \%$ ) measured in the concretions of sub-seafloor sediments from the rim of the brine lake, and with the values $(-1.3$ to $-0.7 \%$ ) measured in the carbonate fraction of the muddy brine. It can be inferred that other carbonate concretions from bottom lake sediments and subseafloor sediments near the brine lake rim showing less depleted $\delta^{18} \mathrm{O}$ values were precipitated at temperatures between $14{ }^{\circ} \mathrm{C}$ and $42{ }^{\circ} \mathrm{C}$.

\subsection{Sources of carbon}

The very low $\delta^{13} \mathrm{C}$ values of the carbonate crusts clearly indicate that these authigenic carbonates were derived from AOM. Similar conclusions have been drawn by Gontharet et al. (2007) for carbonate crusts from the Mykerinos, Chephren and Cheops MVs of the Menes caldera (cf. Huguen et al. 2009). The bulk carbonate from the crusts comprises a small amount (maximum $\sim 10 \%$ ) of carbonate (coccoliths, foraminifers) from pelagic sediments trapped during cementation. A simple mass balance calculation between the pure MDAC component and the carbonate of the pelagic sediment serves to deduce the $\delta^{13} \mathrm{C}$ value of the MDAC: $\delta^{13} \mathrm{C}$ crust $=0.9\left(\delta^{13} \mathrm{CMDAC}\right)+0.1\left(\delta^{13} \mathrm{C}\right.$ sediment $)$. With an average $\delta^{13} \mathrm{C}$ value of $+1.0 \%$ for the sedimentary carbonate and the lowest $\delta{ }^{13} \mathrm{C}$ value of the crust $(-42.6 \%)$, the calculated $\delta^{13} \mathrm{C}$ value of MDAC is $-47.4 \%$. 
It is then possible to evaluate the carbon isotopic composition of the $\mathrm{CH}_{4}$ source using an average isotopic fractionation during $\mathrm{AOM}\left(\mathrm{aCH}_{4}-\mathrm{CO}_{2}\right.$ of 1.008; Alperin et al. 1988) and the isotopic fractionation during carbonate precipitation (the isotopic enrichment factor $\varepsilon^{13} \mathrm{C} \mathrm{CO}_{2}-$ calcite is -12 at $14{ }^{\circ} \mathrm{C}$; Bottinga 1969). This calculation gives a $\mathrm{CH}_{4} \delta^{13} \mathrm{C}$ value of $-51.4 \%$, which falls in the upper range of microbial methane ( -110 to $-50 \%$ V-PDB; Whiticar 1999), although it may better correspond to a mixture of microbial and thermogenic methane (-50 to $-20 \%$ V-PDB; Whiticar 1999). This interpretation is in good agreement with the results of Prinzhofer and Deville (2013), in which the hydrocarbon gas composition and the $\delta^{13} \mathrm{C}$ value of $\mathrm{CH}_{4}(-56.8 \%$ ) measured at the Cheops $\mathrm{MV}$ point to a major thermogenic hydrocarbon gas component. Migration of thermogenic methane is not surprising for the Nile deep-sea fan, a well-known gas province where reservoir rocks are known mostly for the Miocene and Pliocene, the hydrocarbon source rocks being inferred to be of Oligocene and Miocene, and possibly Jurassic and Cretaceous age (Vandré et al. 2007).

The carbonate $\delta^{13} \mathrm{C}$ values of concretions from the sub-seafloor and bottom lake sediments are distributed between two end-members, one with a very low $\delta_{13}^{13} \mathrm{C}$ value and another with a slightly negative $\delta^{13} \mathrm{C}$ value, spanning a range of $\sim 33 \%$; the carbonate $\delta^{13} \mathrm{C}$ values of the muddy brine fall within this range (Fig. 10). As discussed above, the diagenetic carbonates of the concretions were precipitated with two types of bicarbonate ions, originating either from $\mathrm{CO}_{2}$ or from $\mathrm{CH}_{4}$. These two gases are produced during methanogenesis with a huge carbon isotopic fractionation effect (average enrichment factor $\varepsilon^{13} \mathrm{C} \mathrm{CH}_{4}-\mathrm{CO}_{2}$ of $-80 \%$; Rosenfeld and Silverman 1959; Claypool and Kaplan 1974), whereby $\mathrm{CH}_{4}$ is enriched in the light carbon isotope and $\mathrm{CO}_{2}$ is enriched in the heavy carbon isotope relative to the organic carbon source ( $\delta^{13} \mathrm{C}$ of ca. -25 to $-20 \%$ for marine organic matter). Although it is impossible to evaluate the relative proportions of the various carbonate minerals intimately mixed in the concretions and, thus, to separate them for individual analyses, a qualitative estimation of their respective carbon isotopic composition is possible. SEM observations show that Mg-calcite and ankerite were more abundant in the concretions of the sub-seafloor and bottom lake sediments respectively. It follows that $\mathrm{Mg}$-calcite, which dominates in the concretions with the most negative $\delta^{13} \mathrm{C}$ values, originated from the anaerobic oxidation of ${ }^{13} \mathrm{C}$-depleted $\mathrm{CH}_{4}$, whereas ankerite, which dominates in the concretions with slightly negative $\delta^{13} \mathrm{C}$ values, originated mostly from ${ }^{13} \mathrm{C}$-rich $\mathrm{CO}_{2}$.

\section{Conclusions}

The Cheops mud volcano represents an exceptional case of active seepage of hot hydrocarbon-rich muddy brines in the eastern Mediterranean Sea. The brines, which originate from below the Messinian salt deposits ( $>2 \mathrm{~km}$ below the seafloor), actively feed a deep lake ( $\sim 50 \mathrm{~m}$ depth at least at one site) at the seafloor, as shown by evidence of fresh mudslides down the northern flank of the mud volcano and of active brine motion within pools. Consequently, the colonization of the seafloor by microbial mats and polychaetes as well as the development of authigenic carbonate crusts are limited to the periphery of the mud volcano on older mud breccia deposits.

The physicochemical characteristics of the fluids emitted at the Cheops MV leave a distinct imprint on the diagenetic evolution of this system compared to other cold seeps known on the Nile deep-sea fan (Gontharet et al. 2007; Mastalerz et al. 2009). The relatively high temperature $\left(42^{\circ} \mathrm{C}\right)$ of the brine must significantly enhance the kinetics of all biogeochemical reactions, including microbial activity. Acetatebased methanogenesis is active within the muddy brine lake where dolomite and ankerite precipitate. The very high salinity of fluids decreases the solubility of gases and creates very strong density and chemical gradients that reduce the exchanges between pore fluids and bottom seawater. Moreover, the burrowing activity of polychaetes acts to irrigate sub-seafloor sediments with oxygenated and sulphaterich bottom water, which in turn promotes both aerobic and anaerobic oxidation of methane and thus controls the emission of methane in the water column above the Cheops mud volcano.

These findings imply that the coupling of carbon and sulphur microbial reactions represents the major link for the transfer of elements (major, trace, REEs) and for the carbon isotope fractionation between fluids and authigenic minerals at the Cheops mud volcano. A new challenge awaiting future studies in 
cold seep environments is to investigate the oxygen and sulphur isotope signatures of oxidized and reduced sulphur authigenic minerals (gypsum, barite, pyrite), in order to explore sulphate reduction and sulphide oxidation processes.

\section{Acknowledgements}

We thank the crews and scientific party of the Medeco2 expedition aboard the R/V Pourquoi pas ? with the Ifremer ROV Victor, and are especially grateful to Laëtitia Brosolo for the processing of bathymetric data. The work was supported by HERMES (EC Contract No. GOCE-CT-2005-511234) and HERMIONE (EC Contract No. FP7-ENV-2008-1-226354) programmes funded by the European Commission's Framework Six and Seven programmes. We acknowledge two anonymous reviewers and Patrice Imbert as a guest editor of the Special Issue GIMS11 Nice for their valuable comments on the earlier version of the manuscript, as well as the journal editors for additional remarks.

\section{References}

Aloisi G, Pierre C, Rouchy JM, Foucher JP, Woodside J, the Medinaut Scientific Party (2000) Methanerelated authigenic carbonates of eastern Mediterranean Sea mud volcanoes and their possible relation to gas hydrate destabilisation. Earth Planet Sci Lett 184:231-338

Aloisi G, Wallmann K, Bollwerk SM, Derkachev A, Bohrmann G, Suess E (2004) The effect of dissolved barium on biogeochemical processes at cold seeps. Geochim Cosmochim Acta 68(8):1735-1748

Alperin MJ, Reeburg WS, Whiticar MJ (1988) Carbon and hydrogen isotope fractionation resulting from anaerobic methane oxidation. Global Biogeochem Cycles 2(3):279-288

Barrat JA, Keller F, Amossé J, Taylor RN, Nesbitt RW, Hirata T (1996) Determination of rare earth element in sixteen silicate reference samples by ICP-MS after Tm addition and ion exchange separation. Geostand Newslett 20:133-139

Bayon G, Loncke L, Dupré S, Caprais JC, Ducassou E, Duperron S, Etoubleau J, Foucher JP, Fouquet Y, Gontharet S, Henderson GM, Hughen C, Klaucke I, Mascle J, Migeon S, Olu-Le Roy K, Ondréas H, Pierre C, Sibuet M, Stadnitskaia A, Woodside J (2009) Multidisciplinary investigation of fluid seepage on an unstable margin: the case of the Central Nile Deep-sea fan. Mar Geol 261:92104

Bayon G, Birot D, Ruffine L, Caprais JC, Ponzevera E, Bollinger C, Donval JP, Charlou JL, Voisset M (2011) Evidence for intense REE scavenging at cold seeps from the Niger Delta margin. Earth Planet Sci Lett 312:443-452

Bayon G, Dupré S, Ponzevera E, Etoubleau J, Chéron S, Pierre C, Mascle J, Boetius A, de Lange G (2013) Formation of carbonate chimneys in the Mediterranean Sea linked to deepwater oxygen depletion. Nature Geosci 6:755-760. doi:10.1038/ngeo1888

Boetius A, Wenzhöfer F (2013) Seafloor oxygen consumption fuelled by methane from cold seeps. Nature Geosci 6:725-734. doi:10.1038/ngeo1926

Boetius A, Ravenschlag K, Schubert CJ, Rickert D, Widdel F, Gieseke A, Amann R, Jørgensen BB, Witte U, Pfannkuche $O$ (2000) A marine consortium apparently mediating anaerobic oxidation of methane. Nature 407:623-626

Bottinga $Y$ (1969) Calculated fractionation factors for carbon and hydrogen isotope exchange in the system calcite-CO2-graphite-methane-hydrogen and water vapor. Geochim Cosmochim Acta 33:49-64

Burton EA, Walter LM (1987) Relative precipitation rates of aragonite and Mg calcite from seawater: temperature or carbonate ion control? Geology 15:111-114

Carothers WW, Adami LH, Rosenbauer RJ (1988) Experimental oxygen isotope fractionation between siderite-water and phosphoric acid-liberated CO2-siderite. Geochim Cosmochim Acta 52:24452450

Claypool GE, Kaplan IR (1974) The origin and distribution of methane in marine sediments. In: Kaplan IR (ed) Natural gases in marine sediments. Plenum, New York, pp 99-139

Claypool GE, Threlkeld CN (1983) Anoxic diagenesis and methane generation in sediments of the Blake Outer Ridge, Deep Sea Drilling Project Site 553, Leg 76. In: Sheridan RE, Gradstein FM et al., Init Repts DSDP 76. US Govt Printing Office, Washington, pp 391-402 
Craig H (1957) Isotopic standards for carbon and oxygen and correction factors for massspectrometric analysis of carbon dioxide. Geochim Cosmochim Acta 12:133-149

Crémière A, Pierre C, Blanc-Valleron MM, Zitter T, Cagatay NM, Henry P (2012) Methanederived authigenic carbonates along the North Anatolian fault system in the Sea of Marmara (Turkey). Deep Sea Res I 66:114-130

Dickens GR (2001) Sulfate profiles and barium fronts in sediment on the Blake Ridge: present and past methane fluxes through a large gas hydrate reservoir. Geochim Cosmochim Acta 65:529-543

Dupré S, Woodside J, Foucher JP, de Lange G, Mascle J, Boetius A, Mastalerz V, Stadnistskaia A, Ondréas H, Huguen C, Harmégnies F, Gontharet S, Loncke L, Deville E, Niemann H, Omoregie E, Olu-Le Roy K, Fiala-Medioni A, Dählmann A, Caprais JC, Prinzhofer A, Sibuet M, Pierre C, Sinninghe Damsté J (2007) Seafloor geological studies above active gas chimneys off Egypt (Central Nile deepsea fan). Deep Sea Res I 54:1146- 1172

Dupré S, Buffet G, Mascle J, Foucher J-P, Gauger S, Boetius A, Marfia C, the AsterX AUV Team, the Quest ROV Team, the BIONIL Scientific Party (2008) High-resolution mapping of large gas emitting mud volcanoes on the Egyptian continental margin (Nile Deep Sea Fan) by AUV surveys. Mar Geophys Res 29(4):275-290

Dupré S, Woodside J, Klaucke I, Mascle J, Foucher J-P (2010) Widespread active seepage activity on the Nile Deep Sea Fan (offshore Egypt) revealed by high-definition geophysical imagery. Mar Geol 275(1/4):1-19

Feng D, Lin ZJ, Bian YY, Chen DF, Peckmann J, Bohrmann G, Roberts HH (2013) Rare earth elements of seep carbonates: Indication for redox variations and microbiological processes at modern seep sites. J Asian Earth Sci 65:27-33

Foucher J-P, Westbrook GK, Boetius A, Ceramicola S, Dupré S, Mascle J, Mienert J, Pfannkuche O, Pierre C, Praeg D (2009) Structure and drivers of hydrocarbon seep ecosystems in the European seas: an overview from HERMES results. Oceanography 22(1):92-109

Fritz P, Smith DGW (1970) The isotopic composition of secondary dolomites. Geochim Cosmochim Acta 34:1161-1173

Goldsmith JR, Graf DL, Heard HC (1961) Lattice constants of the calcium-magnesium carbonates. Am Mineral 46:453-457

Gontharet S, Pierre C, Blanc-Valleron MM, Rouchy JM, Fouquet Y, Bayon G, Foucher JP, Woodside J, Mascle J, the Nautinil scientific party (2007) Nature and origin of diagenetic carbonate crusts and concretions from mud volcanoes and pockmarks of the Nile deep-sea fan (eastern Mediterranean Sea). Deep Sea Res II 54:1292-1311

Gontharet S, Stadnitskaia A, Bouloubassi I, Pierre C, Dinninghe Damsté JS (2009) Palaeo methaneseepage history traced by biomarker patterns in a carbonate crust, Nile deep-sea fan (Eastern Mediterranean Sea). Mar Geol 261:105-113 Grossman EL, Ku TL (1986) Carbon and oxygen isotope fractionation in biogenic aragonite: temperature effects. Chem Geol 59:59-74

Himmler T, Brinkmann F, Bohrmann G, Peckmann J (2011) Corrosion patterns of seepcarbonates from the eastern Mediterranean Sea. Terra Nova 23:206-212

Himmler T, Haley BA, Torres ME, Klinkhammer GP, Bohrmann G, Peckmann J (2013) Rare earth element geochemistry in cold-seep pore waters of Hydrate Ridge, northeast Pacific Ocean. GeoMar Lett 33(5):369-379. doi:10.1007/s00367-013-0334-2

Hinrichs KU, Summons RE, Orphan V, Sylva SP, Hayes JM (2000) Molecular and isotopic analysis of anaerobic methane-oxidizing communities in marine sediments. Org Geochem 31:1685-1701

Huguen C, Mascle J, Chaumillon E, Kopf A, Woodside J, Zitter T (2004) Structural setting and tectonic control of mud volcanoes in the central Mediterranean Ridge (Eastern Mediterranean). Mar Geol 209:245-263

Huguen C, Zitter T, Woodside J, Mascle J, Foucher JP (2005) Mud volcanoes and mud domes of the Central Mediterranean Ridge: near bottom and in situ observations. Deep Sea Res 52:1911-1931

Huguen C, Foucher JP, Mascle J, Ondréas H, Thouement M, Gontharet S, Stadnitskaia A, Pierre C, Bayon G, Loncke L, Boetius A, Bouloubassi I, de Lange G, Caprais JC, Fouquet Y, Woodside JM, Dupré S, the NAUTINIL Scientific Party (2009) Menes caldera, a highly active site of brine seepage in the Eastern Mediterranean Sea: in situ observations from the Nautinil expedition (2003). Mar Geol 261:138-152

Joye SB, Samarkin VA, Orcutt BN, MacDonald IR, Hinrichs KU, Elvert M, Teske AP, Lloyd KG, Lever MA, Montoya JP, Meile CD (2009) Metabolic variability in seafloor brines revealed by carbon and sulphur dynamics. Nature Geosci 2:349-354. doi:10.1038/ngeo475 
Judd AG, Hovland M (2007) Seabed fluid flow. The impact on geology, biology and the marine environment. Cambridge University Press, Cambridge

Kim ST, O'Neil JR (1997) Equilibrium and nonequilibrium oxygen isotope effects in synthetic carbonates. Geochim Cosmochim Acta 61(16):3461-3475

Loncke L (2002) Le delta profond du Nil: structure et évolution depuis le Messinien. Thèse de doctorat, Université Pierre et Marie Curie, Paris

Loncke L, Mascle J (2004) Mud volcanoes, gas chimneys, pockmarks and mounds on the Nile deep seafan (Eastern Mediterranean): geophysical evidences. Mar Petrol Geol 21:669-689

Loncke L, Gaullier V, Mascle J, Vendeville B, Camera L (2006) The Nile deep-sea fan: an example of interacting sedimentation, salt tectonics, and inherited subsalt paleotopographic features. Mar Petrol Geol 23(3):297-315

Mascle J, Mascle G (2012) Morphotectonic of the Mediterranean Sea, 1/4 000000 map. CCGM, Paris

Mastalerz V, de Lange GJ, Dählmann A (2009) Differential aerobic and anaerobic oxidation of hydrocarbon gases discharged at mud volcanoes in the Nile deep-sea fan. Geochim Cosmochim Acta 73(13):3849-3863

Omoregie EO, Mastalerz V, de Lange G, Straub KL, Kappler A, Roy H, Stadnitskaia A, Foucher J-P, Boetius A (2008) Biogeochemistry and community composition of iron and sulfur precipitating microbial mats at the Chefren mud volcano (Nile Deep-sea fan, Eastern Mediterranean). Appl Environ Microbiol 74(10):3198-3215

Orphan VJ, House CH, Hinrichs KU, McKeegan KD, DeLong EF (2001) Methaneconsuming archaea revealed by directly coupled isotopic and phylogenetic analysis. Science 293:484-487

Peckmann J, Reimer A, Luth U, Luth C, Hansen BT, Heinicke C, Hoefs J, Reitner J (2001) Methanederived carbonates and authigenic pyrite from the northwestern Black Sea. Mar Geol 177:129-150

Pierre C, Mascle J, Dupré S, the Medeco Leg2 Scientific Party (2008) MEDECO Leg 2 cruise report, R/V Pourquoi pas? 02 to 30 November 2007, Rhodes-Toulon. Ifremer, Paris. http://archimer.ifremer.fr/doc/00134/24550/

Pierre C, Blanc-Valleron M-M, Demange J, Boudouma O, Foucher J-P, Pape T, Himmler T, Fekete N, Spiess V (2012) Authigenic carbonates from active methane seeps offshore southwest Africa. Geo-Mar Lett 32(5/6):501-513. doi:10.1007/s00367-012-0295-x

Prinzhofer A, Deville E (2013) Origins of hydrocarbon gas seeping out from offshore mud volcanoes in the Nile delta. Tectonophysics 591:52-61

Ritt B, Pierre C, Gauthier O, Wenzhöfer F, Boetius A, Sarrazin J (2011) Diversity and distribution of coldseep fauna associated with different geological and environmental settings at mud volcanoes and pockmarks of the Nile Deep-Sea Fan. Mar Biol 158(6):1187-1210. doi:10.1007/s00227-011-16796

Rongemaille E, Bayon G, Pierre C, Bollinger C, Chu NC, Favreau E, Fouquet Y, Riboulot V, Voisset M (2011) Rare earth elements in cold seep carbonates from the Niger Delta. Chem Geol 286:196206

Rosenfeld WD, Silverman SR (1959) Carbon isotope fractionation in bacterial production of methane. Science 130:1658-1659

Sardou O, Mascle J (2003) Cartography by multibeam echo-sounder of the Nile deep-sea Fan and surrounding areas. 2 sheets, special publication CIESM, Monaco

Stadnitskaia A, Nadezhkin D, Abbas B, Blinova V, Ivanov MK, Sinninghe Damsté JS (2008) Carbonate formation by anaerobic oxidation of methane: evidence from lipid biomarker and fossil 16S rDNA. Geochim Cosmochim Acta 72:1824-1836

Tarutani T, Clayton RN, Mayeda TK (1969) The effect of polymorphism and magnesium substitution of oxygen isotope fractionation between calcium carbonate and water. Geochim Cosmochim Acta 33:987-996

Torres ME, Bohrmann G, Dubé TE, Poole FG (2003) Formation of modern and Paleozoic stratiform barite at cold methane seeps on continental margins. Geology 31:897-900

Vandré C, Cramer B, Gerling P, Winsemann J (2007) Natural gas formation in the western Nile delta (Eastern Mediterranean): thermogenic versus microbial. Org Geochem 38:523-539

Wallmann K, Aloisi G, Haeckel M, Tishchenko P, Pavlova G, Greinert J, Kutterfolf S, Eisenhauer A (2008) Silicate weathering in anoxic marine sediments. Geochim Cosmochim Acta 72:3067-3090

Whiticar MJ (1999) Carbon and hydrogen isotope systematics of bacterial formation and oxidation of methane. Chem Geol 161:291-314 Woodside JM, Volgin AV (1996) Brine pools associated with Mediterranean Ridge mud diapirs: an interpretation of echo-free patches in deep tow sidescan sonar data. Mar Geol 132:55-61 


\begin{tabular}{|c|c|c|c|c|}
\hline Sample code & Type of sample & $\begin{array}{l}\text { Water } \\
\text { depth }(\mathrm{m})\end{array}$ & Latitude N & Longitude E \\
\hline $\begin{array}{l}\text { MD2-342- } \\
\text { MBS }\end{array}$ & Muddy brine, crater lake & 2,994 & 32.08 .1362 & 28.09 .5032 \\
\hline $\begin{array}{l}\text { MD2-343-PC9 } \\
\text { (push core) }\end{array}$ & $\begin{array}{l}\text { Sub-seafloor sediments, foot of } \\
\text { MV NE flank }\end{array}$ & 3,015 & 32.08 .4850 & 28.09 .7140 \\
\hline $\begin{array}{l}\text { MD2-342- } \\
\text { BC5 (blade } \\
\text { core) }\end{array}$ & $\begin{array}{l}\text { Sub-seafloor sediments, MV SE } \\
\text { flank, near crater rim }\end{array}$ & 2,997 & 32.08 .0997 & 28.09 .5844 \\
\hline $\begin{array}{l}\text { MD2-GCT6 } \\
\text { (gravity core) }\end{array}$ & $\begin{array}{l}\text { Brine lake bottom sediments, } 449 \\
\text { m lake depth }\end{array}$ & 2,947 & 32.08 .1568 & 28.09 .4367 \\
\hline $\begin{array}{l}\text { MD2-342- } \\
\mathrm{CC1}\end{array}$ & $\begin{array}{l}\text { Carbonate crust, foot of MV NE } \\
\text { flank }\end{array}$ & 3,015 & 32.08 .4895 & 28.09 .6967 \\
\hline $\begin{array}{l}\mathrm{MD} 2-342- \\
\mathrm{CC} 2\end{array}$ & & 3,015 & 32.08 .4895 & 28.09 .6967 \\
\hline $\begin{array}{l}\text { MD2-342- } \\
\mathrm{CC} 1\end{array}$ & & 3,014 & 32.08 .4823 & 28.09 .7025 \\
\hline $\begin{array}{l}\mathrm{MD} 2-342- \\
\mathrm{CC} 2\end{array}$ & & 3,015 & 32.08 .4823 & 28.09 .6949 \\
\hline $\begin{array}{l}\mathrm{MD} 2-343- \\
\mathrm{CC} 3\end{array}$ & & 3,015 & 32.08 .4823 & 28.09 .6949 \\
\hline
\end{tabular}

Table 1 Locations of samples collected during the Medeco2 expedition at the Cheops mud volcano (cf. Fig. 2) 
MD2-342-CC1 MD2-343-CC2 MD2-343-CC1 MD2-GCT6-1 MD2-GCT6-2

Carbonate crust foot of MV NE flank Brine lake concretions

Bulk carbonate samples (XRF)

\begin{tabular}{|c|c|c|c|c|c|}
\hline $\mathrm{SiO}_{2}(\%)$ & 18.09 & 23.53 & 27.52 & & \\
\hline $\mathrm{Al}_{2} \mathrm{O}_{3}$ & 3.65 & 4.14 & 4.66 & & \\
\hline $\mathrm{Fe} 2 \mathrm{O} 3$ & 1.80 & 2.06 & 2.30 & & \\
\hline $\mathrm{MnO}$ & $<0.01$ & $<0.01$ & 0.01 & & \\
\hline $\mathrm{CaO}$ & 38.51 & 34.95 & 32.57 & & \\
\hline $\mathrm{MgO}$ & 1.09 & 1.09 & 1.14 & & \\
\hline $\mathrm{K}_{2} \mathrm{O}$ & 0.33 & 0.47 & 0.53 & & \\
\hline $\mathrm{Na}_{2} \mathrm{O}$ & 0.69 & 0.76 & 0.80 & & \\
\hline $\mathrm{TiO}_{2}$ & 0.31 & 0.36 & 0.40 & & \\
\hline $\mathrm{P}_{2} \mathrm{O}_{5}$ & 0.09 & 0.09 & 0.07 & & \\
\hline $\mathrm{SO}_{4}$ & 1.00 & 1.55 & 1.45 & & \\
\hline LOI & 33.32 & 30.37 & 28.01 & & \\
\hline Total $(\%)$ & 98.87 & 99.37 & 99.46 & & \\
\hline $\mathrm{Sr}(\mathrm{ppm})$ & 8,896 & 7,097 & 6,681 & & \\
\hline \multicolumn{6}{|c|}{$5 \%$ AA leachates (ICPMS) } \\
\hline $\mathrm{Sr}(\mathrm{ppm})$ & 11,863 & 9,349 & 12,869 & 728 & 471 \\
\hline $\mathrm{Mg}$ & 5,752 & 5,693 & 7,213 & 6,590 & 7,636 \\
\hline $\mathrm{Mn}$ & 90 & 203 & 172 & 5,391 & 3,056 \\
\hline $\mathrm{U}$ & 3.77 & 4.66 & 6.05 & 0.49 & 0.59 \\
\hline $\mathrm{Ba}$ & 312 & 233 & 328 & 38.3 & 29.5 \\
\hline Mo & 0.79 & 1.15 & 3.52 & 0.07 & 0.01 \\
\hline $\mathrm{Rb}$ & 2.51 & 2.74 & 3.69 & 0.78 & 0.88 \\
\hline $\mathrm{La}$ & 5.56 & 7.24 & 8.23 & 9.12 & 7.97 \\
\hline $\mathrm{Ce}$ & 13.98 & 18.02 & 20.62 & 19.20 & 15.37 \\
\hline $\operatorname{Pr}$ & 1.66 & 2.16 & 2.46 & 2.29 & 1.75 \\
\hline $\mathrm{Nd}$ & 6.94 & 9.08 & 10.37 & 9.46 & 7.32 \\
\hline $\mathrm{Sm}$ & 1.54 & 1.99 & 2.28 & 2.03 & 1.50 \\
\hline $\mathrm{Eu}$ & 0.36 & 0.47 & 0.56 & 0.51 & 0.38 \\
\hline Gd & 1.51 & 1.98 & 2.19 & 2.16 & 1.69 \\
\hline $\mathrm{Tb}$ & 0.23 & 0.30 & 0.34 & 0.32 & 0.25 \\
\hline Dy & 1.36 & 1.73 & 1.97 & 1.98 & 1.53 \\
\hline Ho & 0.26 & 0.34 & 0.37 & 0.41 & 0.32 \\
\hline $\mathrm{Er}$ & 0.69 & 0.94 & 0.99 & 1.14 & 0.94 \\
\hline $\mathrm{Yb}$ & 0.58 & 0.71 & 0.78 & 1.02 & 0.85 \\
\hline $\mathrm{Lu}$ & 0.08 & 0.11 & 0.12 & 0.16 & 0.14 \\
\hline Hf & 0.05 & 0.04 & 0.04 & 0.06 & 0.08 \\
\hline Th & 0.43 & 0.32 & 0.25 & 0.21 & 0.25 \\
\hline $\mathrm{Ce} / \mathrm{Ce}^{*}$ & 1.06 & 1.05 & 1.05 & 0.96 & 0.91 \\
\hline
\end{tabular}

Table 2 Major and trace element composition of selected samples collected during the Medeco2 expedition at the Cheops mud volcano. LOI Loss on ignition $\left(1030^{\circ} \mathrm{C}\right)$ 


\section{Figures}
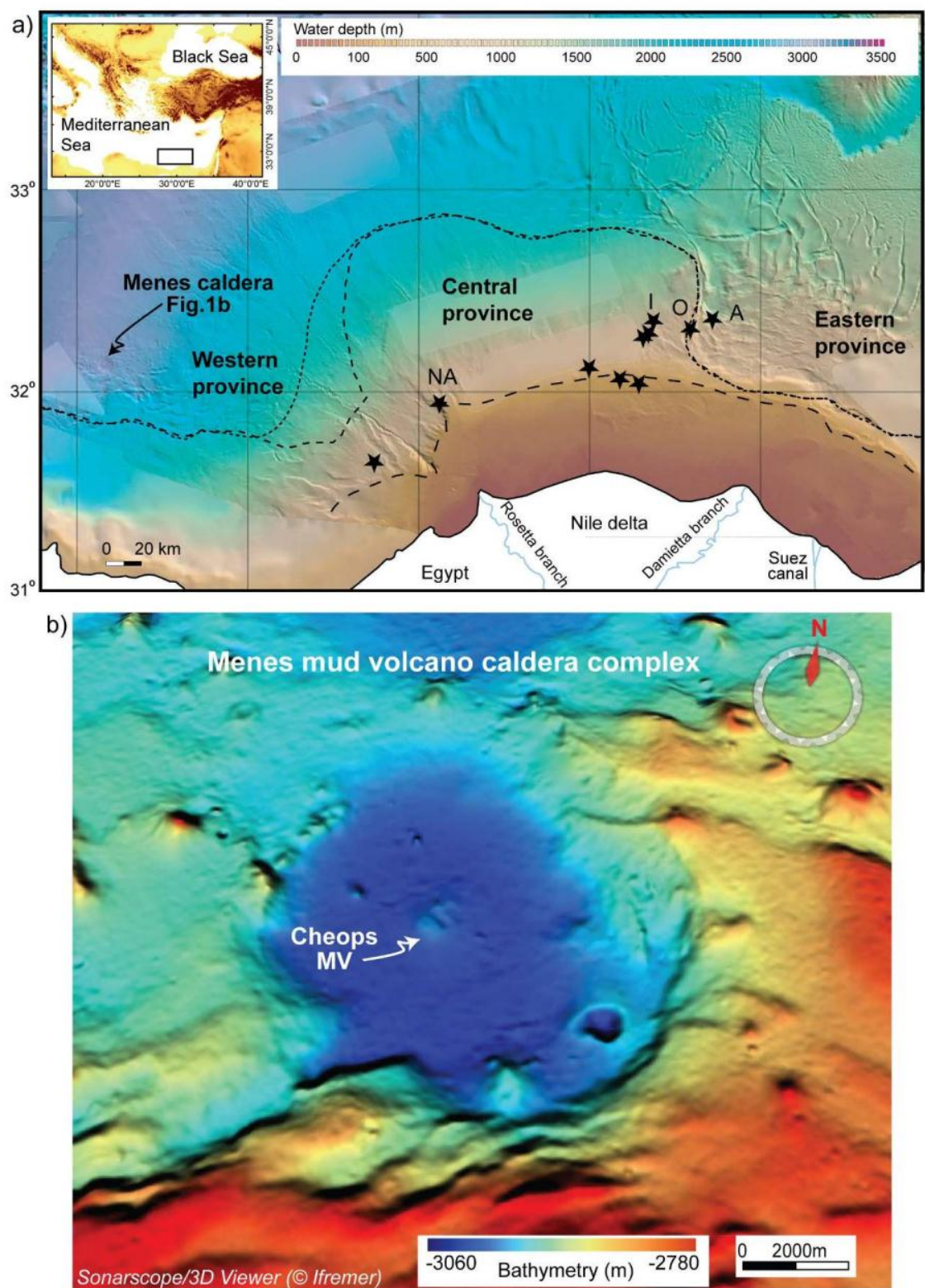

Fig. 1 a) Shaded bathymetric map of the Nile deep-sea fan region (Sardou and Mascle 2003) in the eastern Mediterranean (cf. inset), with locations of the Menes caldera (present study) and some key mud volcanoes (stars) in various provinces demarcated by Loncke et al. (2004). Coarsely hatched line Presentday platform boundary (Loncke 2002), finely hatched line Messinian eroded shelf edge, dotted line southward pinch-out of mobile evaporites (Loncke et al. 2006); NA North Alex, $I$ Isis, $O$ Osiris, A Amon MVs. b) 3D bathymetry of the Menes caldera, with the location of the Cheops MV (VE 10x) 


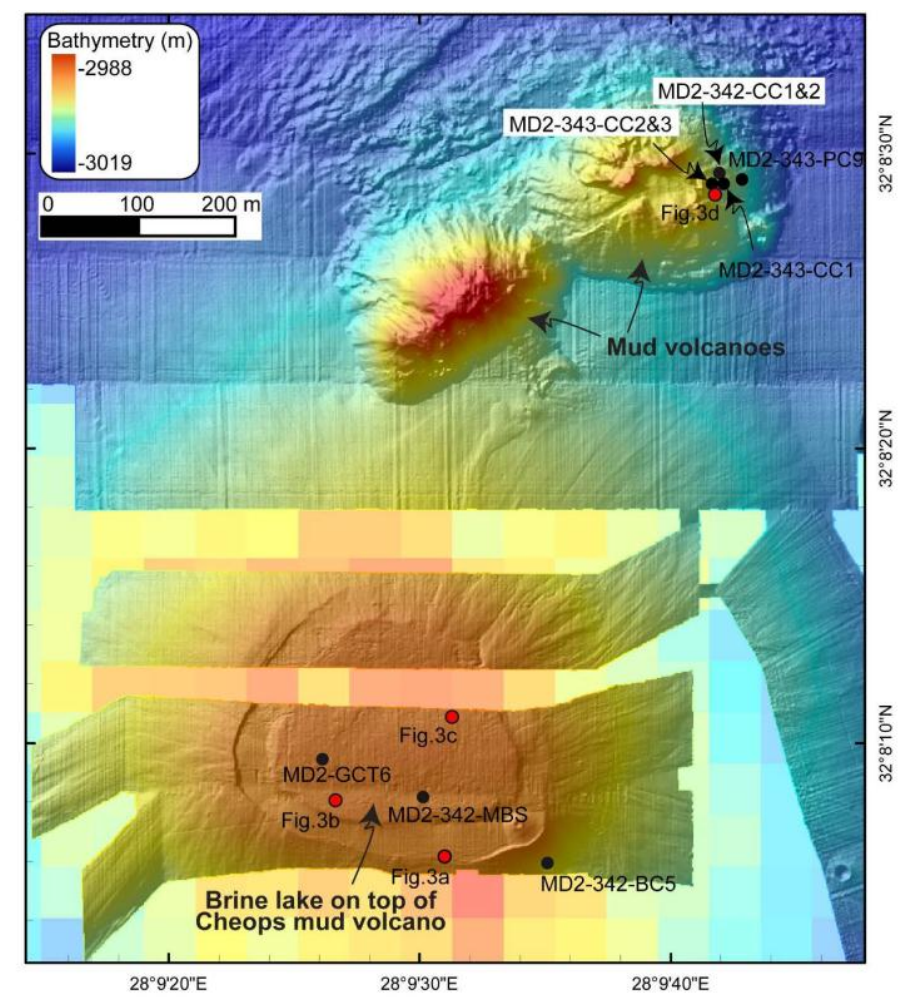

Fig. 2 High-resolution shaded bathymetric map of the Cheops MV and two smaller MVs on its NE flank (Reson 7125 multibeam, $400 \mathrm{kHz}$, Victor $6000 \mathrm{ROV}$, Medeco2 expedition, VE 8x). Note the difference in data resolution between near-bottom and ship-borne multibeam acquisition (1 vs. $50 \mathrm{~m}$ respectively). Also illustrated are the locations of the study samples, and of the seafloor photographs reported in Fig. 3
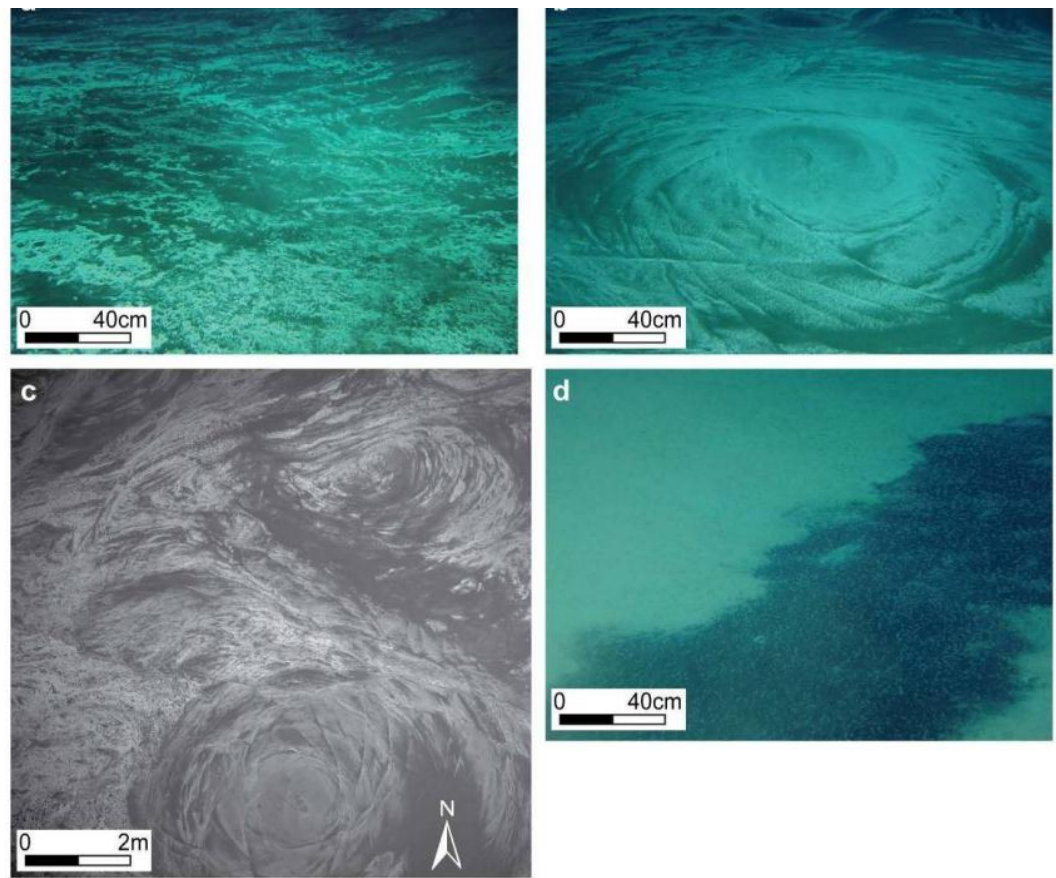

Fig. 3 Close-up photographs of the seafloor at the Cheops MV (Victor 6000 ROV, Medeco2 expedition, () Ifremer). a) White microbial filaments at the surface of muddy brine. b) Crater lake with muddy brine pools. c) Deformation patterns at the surface of the brine lake $(10 \times 10 \mathrm{~m}$ high-resolution black/white photograph, OTUS camera on ROV). d) Brine flow colonized by polychaetes near the foot of the NE flank 

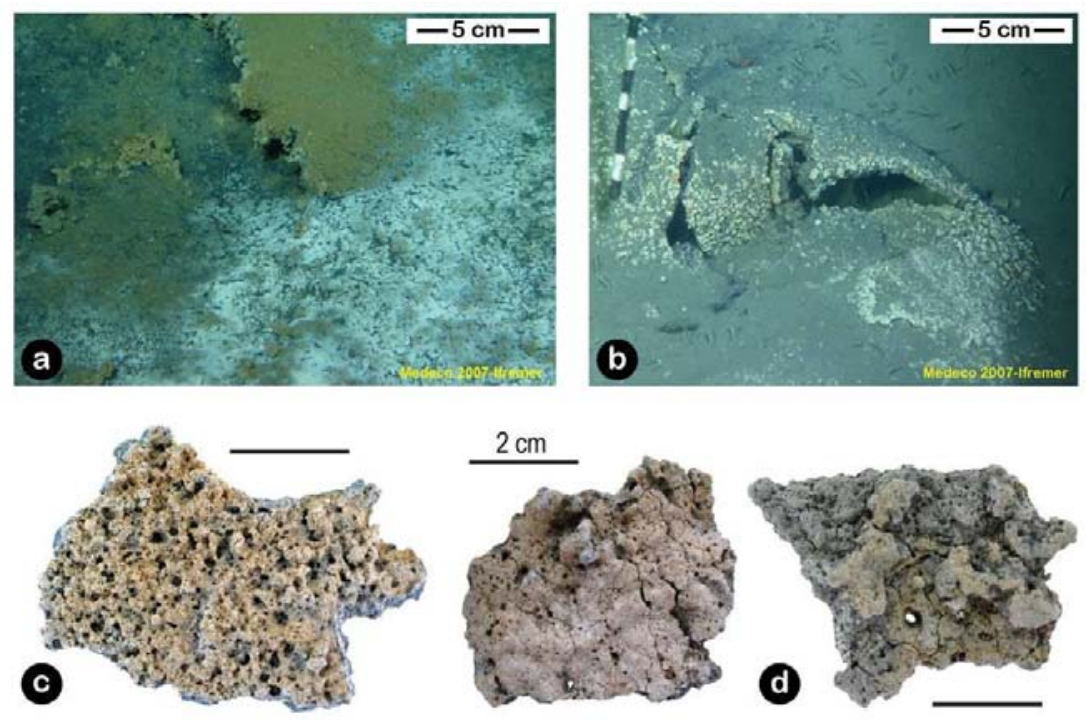

Fig. 4 Authigenic carbonate crusts at the Cheops MV. a) Carbonate crust with white bacterial mat and black patch of reduced sediment, and b) undulated carbonate crust with polychaetes (Victor $6000 \mathrm{ROV}$ images, ( ) Ifremer). c, d) Close-up views of carbonate crust: c sample MD2-343-CC1, d left upper side, right bottom side of sample MD2-342-CC1
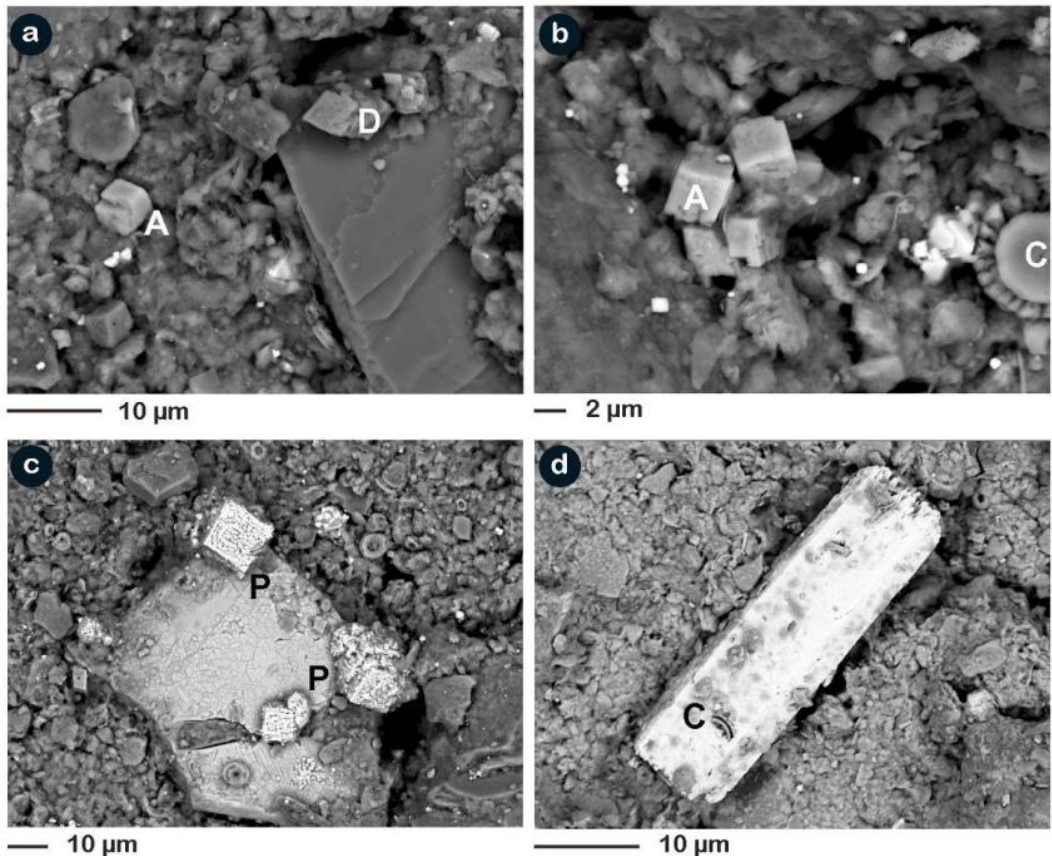

Fig. 5 SEM photographs of muddy brine sediments from the Cheops MV. a) Ankerite (A) and dolomite rhombs (D), pyrite crystals, silicate and clay minerals. b) Ankerite rhombs (A), pyrite, coccolith (C). c) Cubic pyrite aggregates. d) Prismatic crystal of barite including a coccolith $(C)$ and sediments 


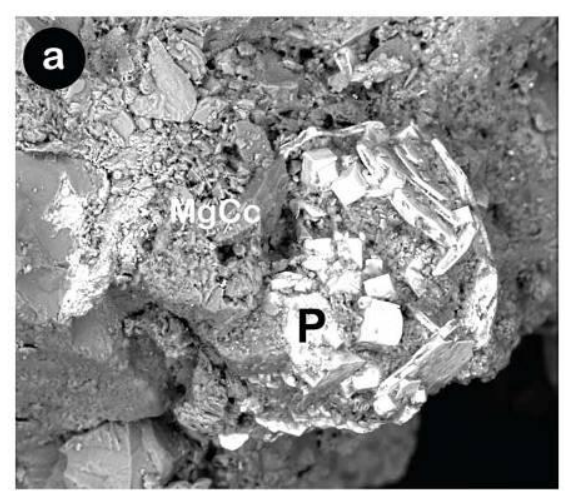

- $10 \mu \mathrm{m}$

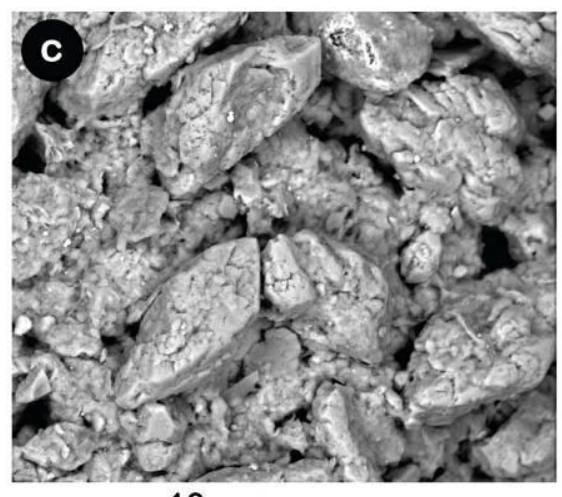

$10 \mu \mathrm{m}$

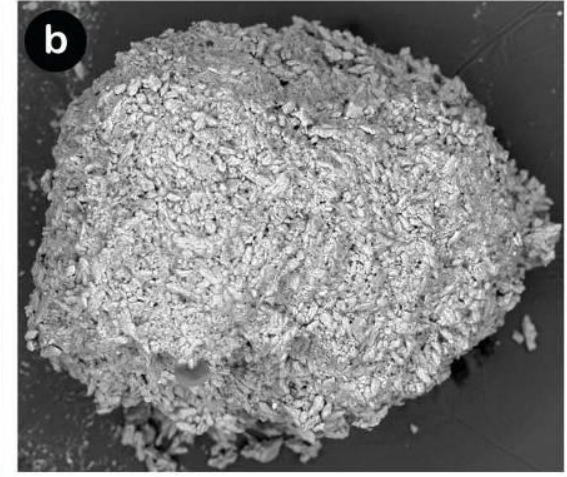

$100 \mu \mathrm{m}$

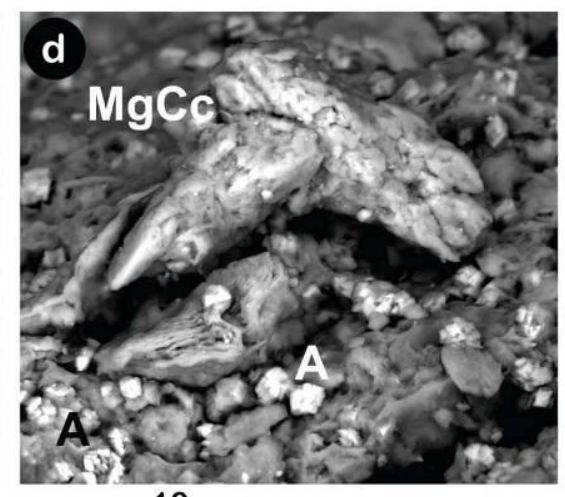

$10 \mu \mathrm{m}$

Fig. 6 SEM photographs of concretions from bottom lake sediments of the Cheops MV. a) Pyrite concretion $(\mathrm{P})$ and $\mathrm{Mg}$-calcite $(\mathrm{MgCc})$ with dissolution cavities. b) Carbonate concretion made up of Mgcalcite. c) Oblong crystals of Mg-calcite with dissolution cavities. d) Ankerite rhombs (A) and Mg-calcite $(\mathrm{MgCc})$

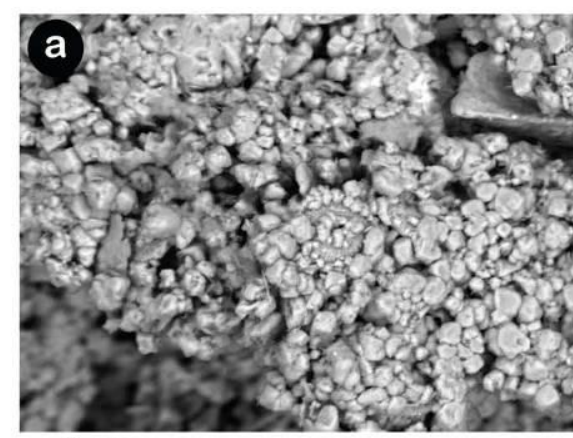

$-2 \mu \mathrm{m}$

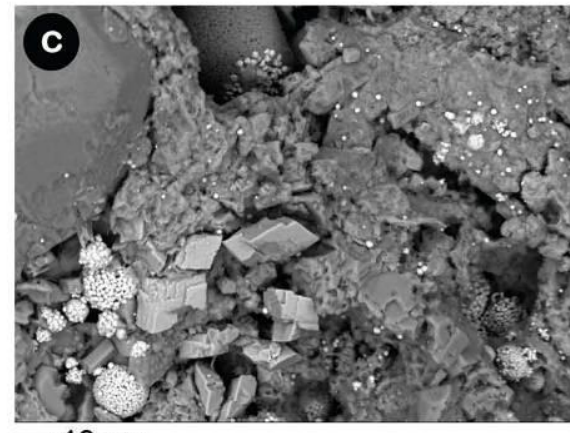

$-10 \mu \mathrm{m}$

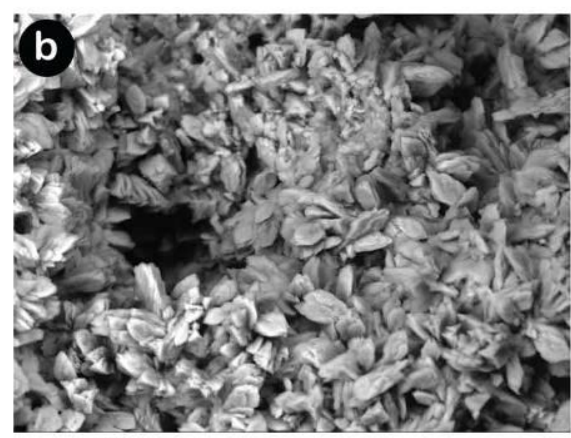

$10 \mu \mathrm{m}$

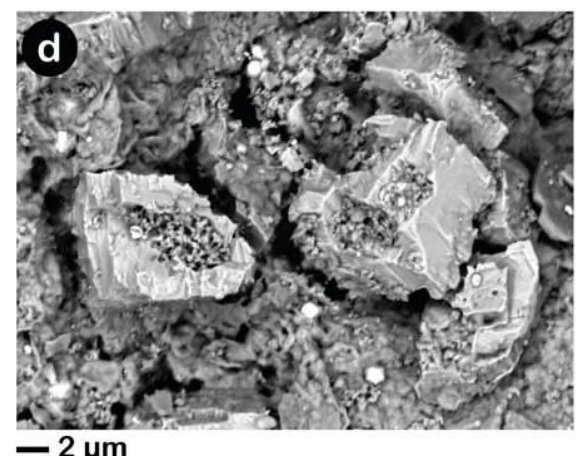

Fig. 7 SEM photographs of concretions of sub-seafloor sediments of the Cheops MV. a) Rounded rhombs of Mg-calcite. b) Prismatic foliated crystals of Mg-calcite. c) Rhombs of ankerite and pyrite framboids in a vein filling between detrital grains. d) Rhombs of ankerite with a core of aggregates of Mgcalcite crystals 

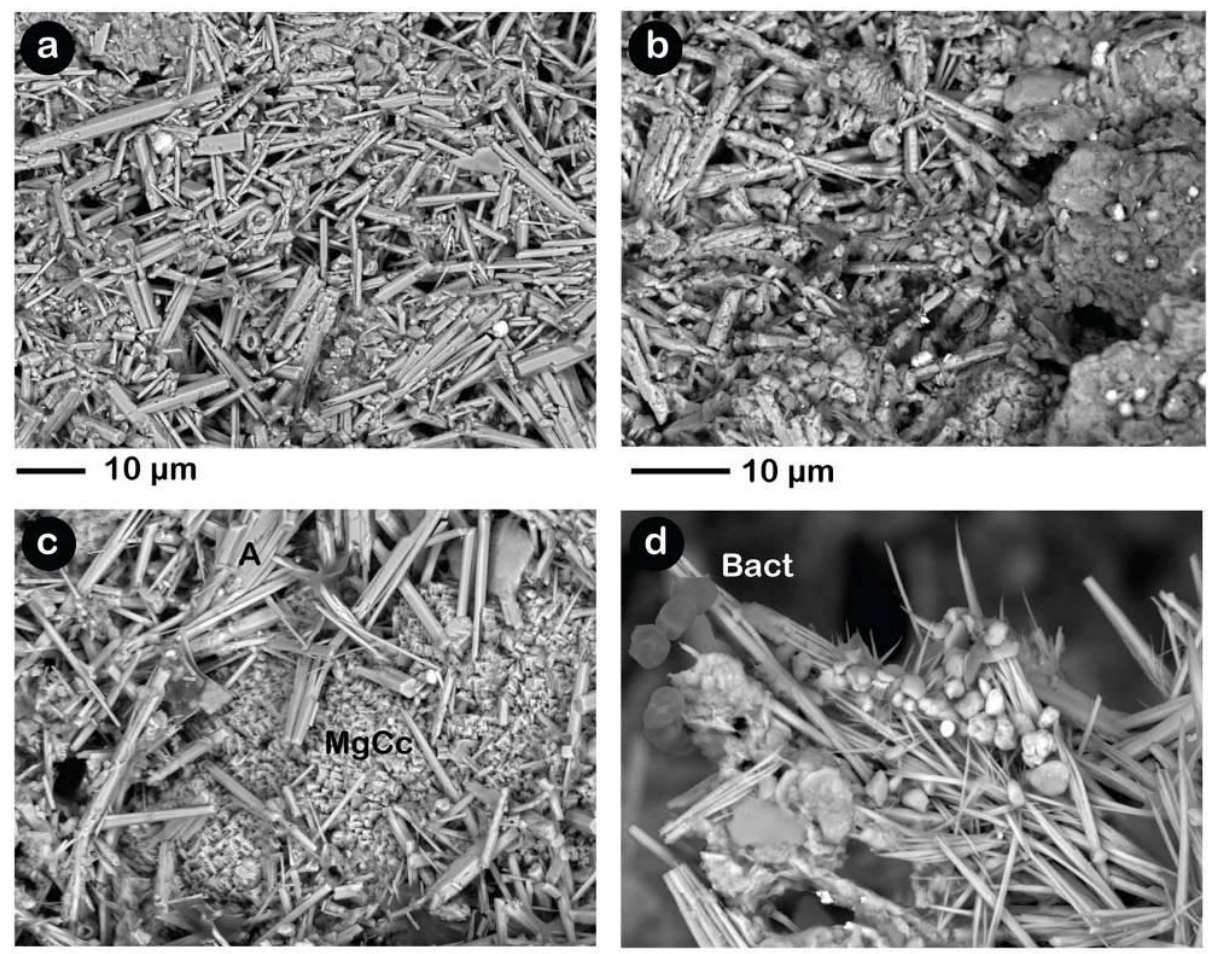

$10 \mu \mathrm{m}$

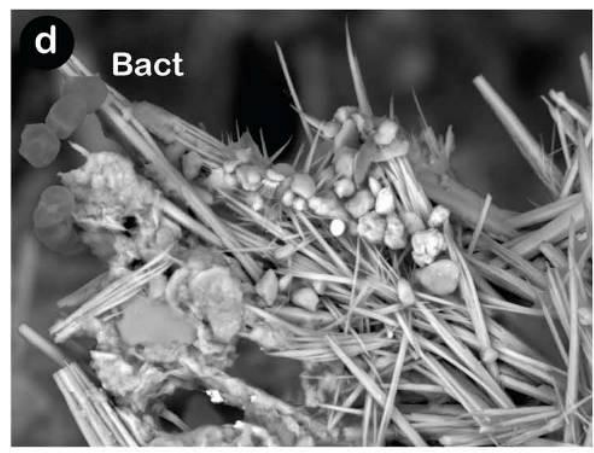

$-2 \mu \mathrm{m}$

Fig. 8 SEM photographs of carbonate crusts of the Cheops MV. a) Aragonite crystals and pyrite. b) Aragonite crystals with dissolution cavities. c) Aragonite and Mg-calcite crystals. d) Crystals of ankerite and bacterial cells (Bact) on aragonite needles

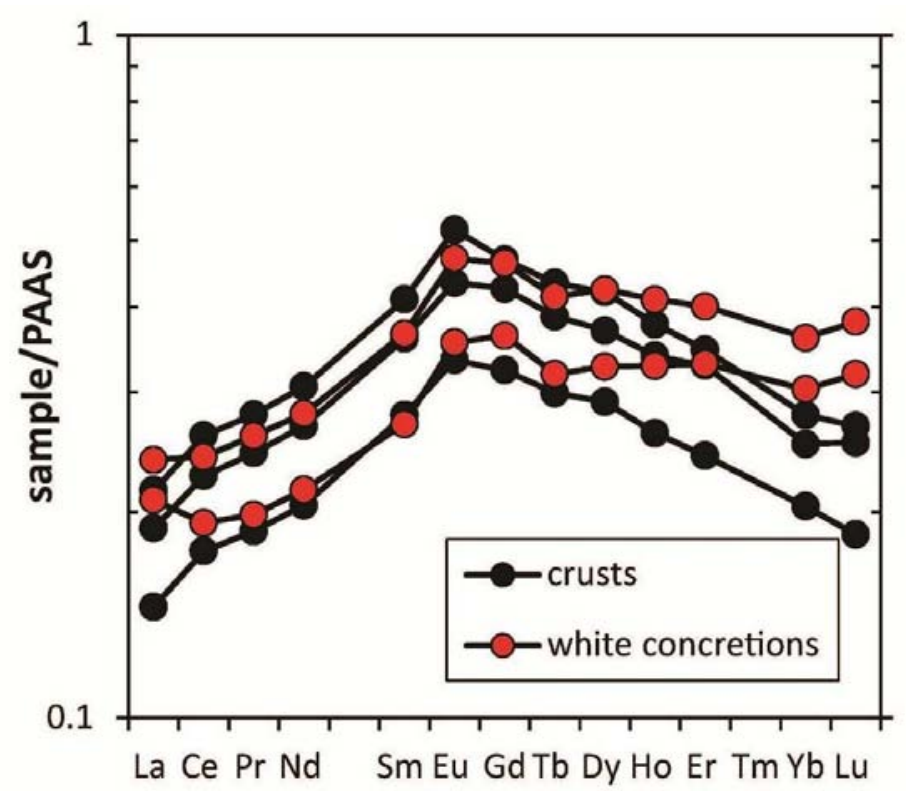

Fig. 9 REE patterns in carbonate crusts and small concretions from bottom lake sediments of the Cheops MV 


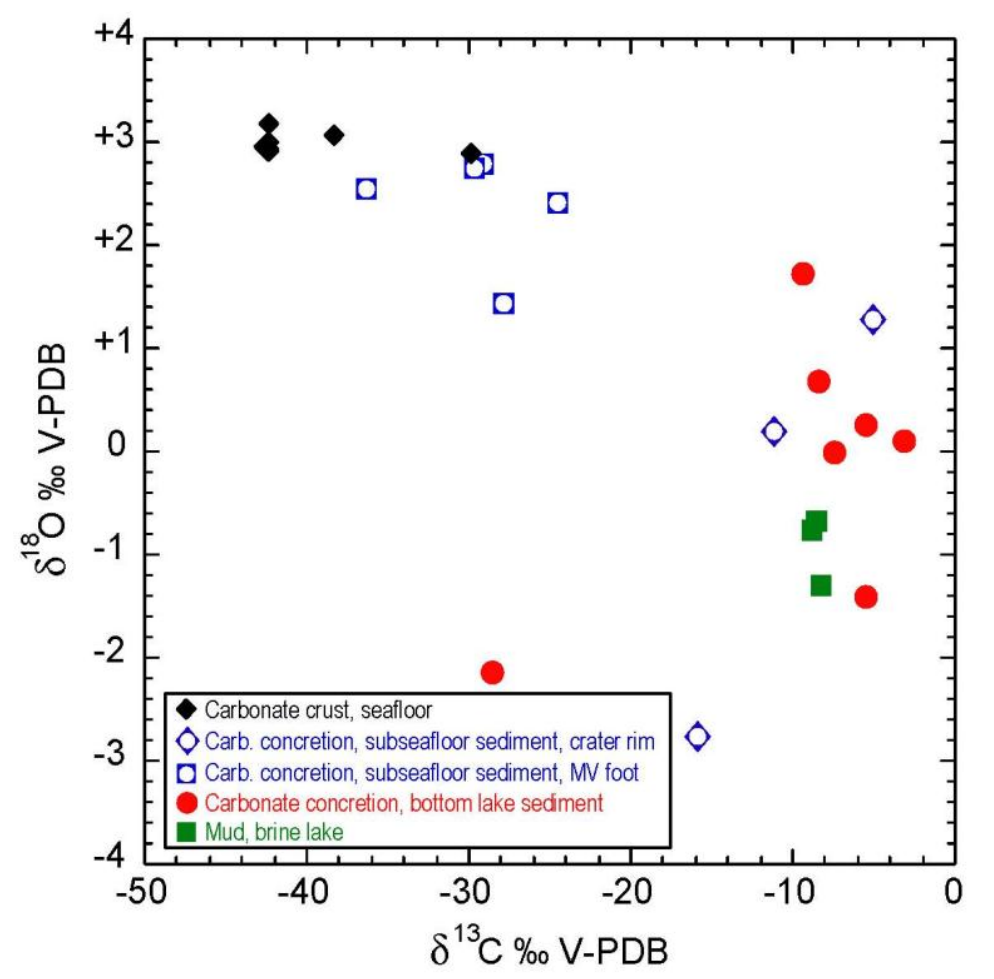

Fig. 10 Oxygen and carbon isotopic compositions of authigenic carbonates from the muddy brine lake $(n=10)$ and the flanks $(n=13)$ of the Cheops MV. The latter dataset comprises two data points extracted from Gontharet et al. (2007). For raw data, see ESM Table 1 in the electronic supplementary material 